\title{
Synergistic approach of structure-based and ligand-based drug design for the development of selective cannabinod receptor ligands
}

\author{
Robert Günther ${ }^{*}$, Peter Brust \\ From 7th German Conference on Chemoinformatics: 25 CIC-Workshop \\ Goslar, Germany. 6-8 November 2011
}

Cannabinoid receptors (CB) are G-protein coupled receptors involved in many physiological processes, like learning, appetite, nociception and others. Two subtypes (termed CB1 and CB2) are involved in slightly different processes [1]. Thus, it is important to gain more insight into the the cannabinoid receptor system and the potential effects of cannabinoid therapeutics.

By combining [2] 3D-QSAR, pharmacophore modeling, comparative modeling and molecular docking we could identify features responsible for receptor subtype specificity.

Various pharmacophore models were derived from inhouse libraries and data available in the literature. 3D structures of both receptor subtypes were created employing comparative modeling methods. The models were subjected to molecular simulations in solvated lipid bilayers to sample different receptor conformations. The models were used for molecular docking studies with small compound libraries. Employing the data obtained in the pharmacophore/3D-QSAR studies as additional constraints delivered valuable information on affinity and selectivity of the compounds towards CB1 and CB2. The results from this synergistic modeling approach could improve our understanding of the protein-ligand interactions involved.

\section{Acknowledgements}

This synergistic approach has been implemented into the MOE modeling package (MOE: Chemical Computing Group Inc. Montreal. H3A 2R7 Canada. http://www.chemcomp.com).

Published: 1 May 2012

\footnotetext{
* Correspondence: r.guenther@hzdr.de

Institute of Radiopharmacy, Helmholtz-Zentrum Dresden-Rossendorf, Research Site Leipzig, Leipzig, 04318 Germany
}

\section{Reference}

1. Pertwee RG: Ligands that target cannabinoid receptors in the brain: from THC to anandamide and beyond. Addict Biol 2008, 13:147-159.

\section{doi:10.1186/1758-2946-4-S1-P11}

Cite this article as: Günther and Brust: Synergistic approach of structurebased and ligand-based drug design for the development of selective cannabinod receptor ligands. Journal of Cheminformatics 2012 4(Suppl 1): P11.

\footnotetext{
Publish with ChemistryCentral and every scientist can read your work free of charge

"Open access provides opportunities to our colleagues in other parts of the globe, by allowing anyone to view the content free of charge."

W. Jeffery Hurst, The Hershey Company.

- available free of charge to the entire scientific community

- peer reviewed and published immediately upon acceptance

- cited in PubMed and archived on PubMed Central

- yours - you keep the copyright

Submit your manuscript here:

http://www.chemistrycentral.com/manuscript/

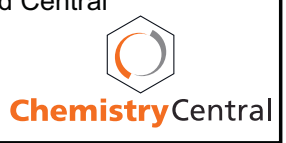

